\title{
An Unified Framework for Measuring E-Service Quality
}

\author{
Mohammed Ateeq Alanezi \\ College of Computing and IT, \\ Shaqra University, Saudi Arabia \\ alanezi.mohd@su.edu.sa
}

\author{
Ali Sellami \\ College of Computing and IT, \\ Shaqra University, Saudi Arabia \\ sellami2003@hotmail.com
}

\begin{abstract}
Companies continually seek efficiency by utilizing the rapid advances in technology to improve their electronic services (e-services). A perusal of the literature shows varying approaches for measuring e-service quality; these approaches have found little consent among reviewers. Therefore, this study attempts to provide a new framework, a roadmap, as a useful model for researchers to measure user perception of e-service quality. For this model, an extensive study is carried and these study findings indicate that system functionality, procedure, content, user support, and manageability should be included in an empirical research model for measuring e- service quality.
\end{abstract}

Keywords-electronic service; e-service quality; framework introduction

\section{INDODUCTION}

Electronic services through the internet have been adopted globally to reduce the cost of operations and improve customer service. However, acceptance of any service is predominantly due to its quality and without comprehensive attention to user acceptability, new services may fail [1]. Quality e-services can provide competitive advantages for online companies by improving performance, increasing productivity, and improving client relationships and thus customer satisfaction and trust [2]. A literature review of the extant e-service quality scales results in a variety of measure dimensions. Unfortunately, these dimensions are conceptualised differently, and there is little consensus for the basics of e-service acceptance $[1,3]$, possibly because the literature is currently inadequate in providing a conceptual framework of e-service quality [4-6]. As a result, many e-service quality researches developed models which may have omitted the user's interaction with the website $[4,7]$. The procedures necessary to navigate through a website for an e-service have become more important as a part of a quality approach. This paper assists such an approach by developing a framework that includes key factors for e-service assessment. This framework provides a useful roadmap to measure users' perceptions of e-service quality.

\section{LITERATURE REVIEW}

This brief survey of recent research findings on e-service quality is presented in two parts. The first one considers conceptualisation of e-service quality and its components, and the second explores theory in the form of technology acceptance models that are applicable in the field.

\section{A. E-Service}

The e-service concept is increasingly used as an important determinant of a successful online environment [4]. Before considering e-service quality, a definition of the term e-service is useful to ground the discussion. Again, there is little agreement regarding the parameters of e-service, as the field has not yet matured [8]. E-service can be simply defined as providing service to users electronically [9]. More elaborately, e-service is defined as "deeds, efforts or performances whose delivery is mediated by information technology. E-service includes the service element of e-tailing, customer support, and service delivery" [8]. For a company, authors in [10] defined eservice as service that takes place from lunching the main page until the requested service has been completed or received, while in public sector, authors in [9] defined e-service as those public services, including information, interaction, communication and transaction services, that are delivered by electronic media to citizens and people who work with or in the e-government sector. By analysing the e-service literature [8], it is found that researchers conceptualized e-services as selfservice or information services, and that e-services are viewed as information services because information is the key value for the user. Authors in [11] distinguished the quality between e-services and self-service. For self-service, a user has to visit a location (e.g. an ATM) to receive the required service, whilst eservice is universally available from the internet. However, in [4], the author disagreed with this difference, claiming all eservices are inherently self-services. E-service, as a concept, has many applications and is located in a number of fields, especially in the forms of e-commerce and e-government. Despite the varying definitions, the researchers agree on the role of technology in facilitating the provision of services to an end user with the objective of improving performance.

\section{B. E-Service Quality}

The study of e-service quality is increasingly recognized and management has directed more attention to the issue in the last few years [1,9]. E-service quality [55] is defined in [12] as the overall consumer evaluations and opinions about the excellence of received e-service in the virtual marketplace. Authors in [13] agreed with this definition, stating that it 
constituted "a customer's experience with the service provider through a given electronic channel without human intervention". However, there are no well-accepted conceptual definitions or models for measuring e-service quality [9], although, as noted, e-service quality is a determinant of successful or failure for online organizations [2, 5, 7, 14]. Many online initiatives have failed due to insufficient attention to e-service quality $[5,7,12]$. As noted, e-service quality studies have increased, and the majority of the research adopted traditional service quality dimensions [15]. The SERVQUAL scale, which was developed for traditional market services, is a popular choice for researchers in the online environment [1, 16]. In [17], it is stated that the SERVQUAL dimensions can be used in an online environment through the addition of technical factors. Some examples of studies that have adopted and extended the SERVQUAL scale are given in [5, 7, 18-20]. Electronic service quality studies are found in banking, libraries, travel agencies, business portals and online shopping fields [1]. In online banking, four factors influence e-banking service quality: personal needs, site organisation, userfriendliness and efficiency [21]. Authors in [22] suggested four factors relating to online shopping service quality: responsiveness, reliability, process, functionality, enjoyment. Timely response, reliability, and courtesy are three factors proposed in [23] to influence the quality of academic library portals, and regarding online travel, authors in [11] posited four factors: presentation, information quality, trust, and responsiveness. In [6], similarly found factors were usability, usefulness of content, adequacy of information, accessibility, and interaction for business portals, while authors in [1] proposed seven dimensions for measuring e-government service quality: website design, reliability, responsiveness, security/privacy, personalisation, information, and ease of use. In the context of online retailers, [24] designated process quality, outcome quality, and recovery quality. Process quality was deconstructed to identify aspects of functionality, information accuracy, design, privacy, and ease of use, whereas outcome quality was determined by order accuracy, order condition, and timeliness, and recovery quality by interactive fairness, procedural fairness, and outcome fairness.

\section{Theories of Acceptance of New Technology}

Researchers use a number of theories to study user acceptance of new technology in information technology and information systems (IT/IS) research. Widely used theories in the IT/IS area are the theory of reasoned action and the technology acceptance model. The theory of reasoned action is a well-accepted model based on factors of intended behaviour [25]. This theory has a conceptual framework that separates beliefs, attitudes, intention and behaviour [26]. An individual's behavior in the reasoned action theory is predicted by behavioral intention which is determined by attitudes and subject norms. Authors in [25] defined the three components of the theory reasoned action as:

- Attitudes: “an individual's positive or negative feeling about performing the target behavior".

- Subjective norms: "the person's perception that most people who are important to him think he should or should not perform the behavior".
- Behavioral intention: "the strength of one's intention to perform the specified behavior".

The assumption that individual behavior is under volitional control is a limitation for the theory of reasoned action, according to [28], as this was not always the case. Thus, the theory of reasoned action was extended into the theory of planned behavior by adding one major predictor, perceived behavioral control and customer satisfaction [28, 44]. Authors in [29] did not entirely accept the theory of reasoned action and suggested certain exceptions by saying "a behavioral intention measure will predict the performance of any voluntary act, unless intent changes prior to performance or unless the intention measure does not correspond to the behavioral criterion in terms of action, target, context, time-frame and/or specificity [29]. The technology acceptance model, developed in 1989 , is the most practicable model for explaining the underlying factors that motivate users to accept and use the new technology in information system research [30]. In a literature analysis in [31], it is claimed that the technology acceptance model is central to IT/IS. This model was originally derived from the theory of reasoned action $[25,32]$. The theory of reasoned action is extended replacing many of its attitude measures with two technology acceptance factors, namely perceived ease of use, and perceived usefulness, as these two factors will influence the user's decision to use the technology [30]. Perceived usefulness is defined in [31] as "the degree to which a person believes that using a particular system would enhance his or her job performance" and perceived ease-of-use is "the degree to which a person believes that using a particular system would be free from effort" [30]. The goal of the developed technology acceptance model was to provide the factors that explained user behavior regarding the use of new technology. The original model, TAM1, extended to TAM2 to explain usage intention by integrating social and cognitive factors such as experience, image, job relevance and voluntariness [33]. In [34], TAM2 was extended to TAM3 by adding factors that assist decision makers regarding interventions that can lead to acceptance and use of technology. Researchers in different domains have used various forms of the acceptance model to evaluate the user acceptance of new technology, including e-commerce [35], e-learning [36], internet banking [24, 37], and e-government [38]. However, the main limitation of the initial model is that it does not include social factors that influence the acceptance the new technology [39]. Author in [40] claimed that the conceptual model lacks sufficient rigour and relevance for it to constitute theory in the information system domain. In addition, the technology acceptance model debate has distracted research attention from other significant issues in the field [41].

\section{Methodology and Analysis}

The relevant literature was reviewed to identify raised issues regarding the relevant models and theories of previous research $[1,2,42]$. The relevant studies were conducted in various contexts, including e-service, online banking, online travel agency, online public library, online retailing, web portal, and online shopping. Table I shows the e-service quality dimensions used in the online environment, the contexts in which they appeared and the frequency of citation. 
TABLE I. A REVIEW OF E-SERVICE QUALITY DIMENSIONS

\begin{tabular}{|c|c|c|}
\hline Dimension & Research context & References \\
\hline \multirow{4}{*}{$\begin{array}{l}\text { Website designs/ } \\
\text { Web site appears/ } \\
\text { Aesthetic design }\end{array}$} & E-service & {$[10,29]$} \\
\hline & Online retailing & {$[25,32]$} \\
\hline & Online shopping & {$[9,52]$} \\
\hline & Online banking & {$[4,7,11,24,27,33]$} \\
\hline \multirow{4}{*}{ Reliability } & E-service & {$[3,18,27,52]$} \\
\hline & Online retailing & {$[9,33,48,53]$} \\
\hline & Online banking & {$[8,17,24,25]$} \\
\hline & Academic and public libraries & {$[12,20,23]$} \\
\hline Delivery & E-service & {$[8,51]$} \\
\hline \multirow{3}{*}{ Ease of use } & E-service & {$[3,10,27,52]$} \\
\hline & Online retailing & {$[8,17,48,53]$} \\
\hline & Online banking & {$[12]$} \\
\hline \multirow{2}{*}{ Efficiency } & Online retailing & {$[7,17,18,32]$} \\
\hline & E-service & {$[12,19]$} \\
\hline \multirow{2}{*}{ Fulfillment } & Online retailing & {$[7,17,18,51]$} \\
\hline & E-service & {$[19,32]$} \\
\hline \multirow{2}{*}{ Privacy } & Online retailing & {$[7,17,18,32]$} \\
\hline & E-service & {$[19]$} \\
\hline \multirow{4}{*}{ Responsiveness } & Online retailing & {$[4,18,27,48]$} \\
\hline & Online banking & {$[17,19,33,53]$} \\
\hline & E-service & {$[7,20,24,25]$} \\
\hline & Online travel & {$[50-52]$} \\
\hline Compensation & Online retailing & {$[7,17-19]$} \\
\hline \multirow{2}{*}{ Contact } & Online retailing & {$[18,19]$} \\
\hline & E-service & {$[7,17]$} \\
\hline Processing speed & Online retailing & {$[10,32]$} \\
\hline \multirow{2}{*}{ Security } & Online retailing & {$[10,12,52,55]$} \\
\hline & E-service & {$[17,20,25,27,48,51]$} \\
\hline \multirow{3}{*}{ Communication } & Online retailing & {$[30,52]$} \\
\hline & E-service & {$[8,32]$} \\
\hline & Online financial services & {$[7,12,34,51]$} \\
\hline Accessibility & Online retailing & {$[6,20,27,29,33,51-53]$} \\
\hline Credibility & Online retailing & {$[27,29,33,52,53]$} \\
\hline Understanding & Online retailing & {$[27,29]$} \\
\hline Availability & Online retailing & {$[19,29,32,51]$} \\
\hline \multirow{4}{*}{ Information } & Online banking & {$[7,27,50,53]$} \\
\hline & Online retailing & {$[6,7,17,32]$} \\
\hline & Online travel & {$[4,51]$} \\
\hline & Web portal & [33] \\
\hline \multirow{2}{*}{ Courtesy } & Online banking & {$[27,33]$} \\
\hline & Academic \& public libraries & {$[23,52]$} \\
\hline \multirow{2}{*}{ Customer service } & Online shopping & {$[9,11]$} \\
\hline & E-service & {$[12]$} \\
\hline Performance & E-service & {$[25]$} \\
\hline Features & E-service & {$[25]$} \\
\hline Service ability & E-service & {$[25]$} \\
\hline System integrity & E-service & {$[25,51]$} \\
\hline \multirow{2}{*}{ Trust } & E-service & {$[8,25,32]$} \\
\hline & Online retailing & {$[4,18,24,50]$} \\
\hline $\begin{array}{c}\text { Service } \\
\text { differentiation }\end{array}$ & E-service & {$[25]$} \\
\hline \multirow{2}{*}{ Customisation } & E-service & {$[8,20,25,51]$} \\
\hline & Online financial services & {$[7,51]$} \\
\hline Web store police & E-service & {$[25]$} \\
\hline Reputation & E-service & {$[25]$} \\
\hline Assurance & E-service & {$[25,55]$} \\
\hline Empathy & E-service & {$[25]$} \\
\hline Response time & Online retailing & {$[4,32]$} \\
\hline Intuitiveness & Online retailing & {$[32]$} \\
\hline Flow & Online retailing & {$[32]$} \\
\hline Innovativeness & Online retailing & {$[32]$} \\
\hline Substitutability & Online retailing & {$[32]$} \\
\hline \multirow{2}{*}{ Interactivity } & Online retailing & {$[32,51]$} \\
\hline & Web portal & {$[6,48,51]$} \\
\hline
\end{tabular}

\begin{tabular}{|c|c|c|}
\hline Structure & E-service & {$[12]$} \\
\hline Content & E-service & {$[2,3,6,8,12,27]$} \\
\hline Linkage & E-service & {$[3,12]$} \\
\hline Incentive & E-service & {$[2,12]$} \\
\hline Convenience & Online retailing & {$[52]$} \\
\hline Competence & Online retailing & {$[33,52]$} \\
\cline { 2 - 3 } & Online shopping & {$[48]$} \\
\hline Personalisation & Online retailing & {$[24,50-52]$} \\
\hline Collaboration & Online retailing & {$[27,52]$} \\
\hline Product portfolio & Online retailing & {$[48]$} \\
\hline Entertainment & Online retailing & {$[4]$} \\
\hline $\begin{array}{c}\text { Transaction } \\
\text { capability }\end{array}$ & Online retailing & {$[7]$} \\
\hline $\begin{array}{c}\text { System } \\
\text { availability }\end{array}$ & E-service & {$[11]$} \\
\hline Graphic style & E-service & {$[8,51]$} \\
\hline $\begin{array}{c}\text { Order } \\
\text { management }\end{array}$ & E-service & {$[6,17,51]$} \\
\hline Functionality & Online financial service & \\
\hline Usability & Web portal & \\
\hline
\end{tabular}

The review of the literature produced more than 50 dimensions relating to e-service and its quality. To analyze these dimensions, a content analysis technique was used. A form of data analysis was proposed by authors in [43] as appropriate to analyze written, verbal or visual communication messages. Part of the set of empirical analysis methods for social research, content analysis is recognised for its validity for text analysis [45]. Qualitative content analysis attends to specific topics that explain the meanings of the phenomenon, rather than counting words or identifying objective content from texts [45]. Content analysis is described as "a research method for the subjective interpretation of the content of text data through the systematic classification process of coding and identifying themes or patterns" [46]. Using suggestions for content analysis processes from $[45,47]$, themes that emerged from these dimensions, were identified and categorized. Based on original definitions, each dimension and its constituent items were first described and prepared for data analysis. Each dimension was identified in relation to the others. Each description was read to note any interesting or relevant information, and this was recorded as a brief note on the page. From these notes, themes emerged, and the themes were sorted and categorised by topic. These were again analyzed and compared with the original description to ensure that the dimension was appropriately themed. Several iterations of this process were undertaken to clarify complicated description of dimensions. When this part of the analysis was complete, the theme groups were then perused to find trends or relationships that could be linked as higher themes and these themes were then modeled.

\section{RESULTS AND DISCUSSION}

The factors relating to e-service quality can be assigned to five themes as shown in Figure 1. These are defined as system functionality, content, manageability, customer support and procedures.

\section{A. System Functionality}

This theme categorizes the technical functions of egovernment websites such as ease of use, system availability, 
privacy and security. System functionality is crucial to provide citizens with a reliable service they are willing to use. Several researchers developed their e-service quality models by using factors within the system functionality theme dimensions in this regard [5, 7, 11, 19, 32]. Certainly, the complexity of system feature and the difficulty to use the services weaken the e-service quality as supported in [7], which claims that problems related to technical functioning of the site lead to frustration and possible user exit. Author in [12] also confirmed that problems related to technical functions influence e-service quality directly and negatively.

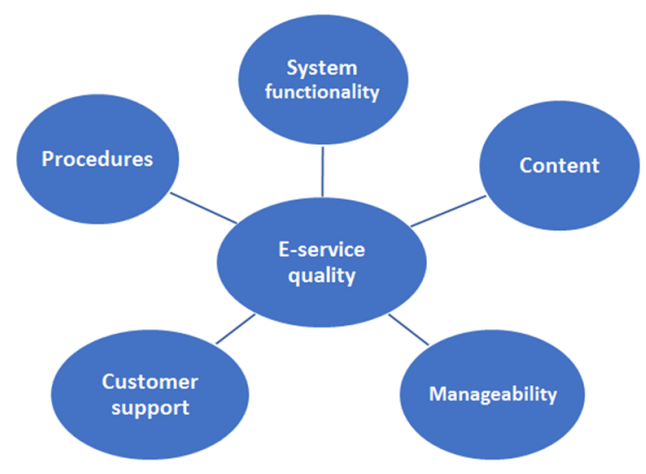

Fig. 1. Conceptual e- service quality framework

\section{B. Content}

This category includes all elements related to the content of the site, presentation, format and information. This category includes text, images, audio and video. These dimensions receive considerable attention $[5,7,48]$. There is a considerable body of evidence showing that better information quality influences e-service quality positively [11, 49-51], while inadequate web design influences e-service quality negatively [7]. Authors in [52] found that content is an important factor in measuring e-service quality.

\section{Manageability}

Manageability [11, 22, 48] relates to efficiency factors of websites, such as processing time and other matters that streamline the website experience. As efficiency underpins the website's usefulness, this theme is interwoven with all other categories. Manageability includes improving processes and improving the user's experience. Failure to deliver a high quality service, failure to deliver service on time and on budget affects project quality [53]. In [53], it is claimed that quality of management provides benchmarking capabilities and comparative assessment of e-services and assists managers to improve the quality of service.

\section{Procedures}

This theme includes all dimensions for e-service quality of work and activities such as credibility, interactivity, and personalization. Procedure was defined as the quality of planning, execution and maintenance of the system work and activities done by e-service's staff behind the system in order to complete the excellent delivery of e-service. Many studies used a dimension that covers the activities under e-service system in order to consider the area of procedure $[5,13,51]$. Failure to perform the promised service and failure to interact with the user affect the quality of e-service. Authors in [51] confirmed that visitors and users are more attracted to interactive than static web sites. Activities built into the website are a service to the end user, so ensuring the quality of operation and content leads to a quality experience. In the e-commerce domain, [48] declared that inaccurate order fulfilment and laxity in keeping service promises are primary elements that negatively influence customer satisfaction.

\section{E. Customer Support}

This category covers all dimensions that envelop user assistance such as responsiveness and contact. The importance of this category is that it helps the users to perform their eservice smoothly by giving them assistance and providing them the needed information. Many studies include some dimension in their models to cover this area in order to measure e-service quality $[5,7,11,54]$. Users expect to be able to complete their request or actions properly, to receive personalized attention, to know how their request is proceeding, to have their enquiries answered quickly, to have contact details and to be able to contact an organization representative directly [11]. Website administrators should ensure these expectations are met [11].

\section{F. Summary}

There is some crossover with these themes, and elements can be classified in more than one category. For example, processing time can be classified as procedure quality as well as manageability quality. This framework was developed to assist researchers and managers in their decision making by using a classification system for the range of elements that may affect e-service quality.

\section{CONCLUSION}

This model can be used as a roadmap for researchers who wish to measure user perception of e-service quality in eservice domains, and for e-service managers and website administrators in assessing the effects of changes to improve their service performance. This novel framework has been produced after reviewing the literature and considering the identified issues. This framework will assist in bringing order to the large number of elements identified as influencing eservice quality, as it takes the user-e-service interface as the nexus for analysis. In addition, this framework will assist developers to understand and evaluate the standards of eservice quality. Future research could consider the relationship between the framework's categories. In addition, researchers can examine these themes in different contexts in order to validate this model.

\section{ACKNOWLEDGEMENT}

Authors would like to thank the Shaqra University for supporting this research. This work had been financed from the Deanship of Scientific Research at Shaqra University, grant Nr. D180326/G01/N002.

\section{REFERENCES}

[1] M. A. Alanezi, A. Kamil, S. Basri, "A proposed instrument dimensions for measuring e-government service quality", International Journal of ue-Service, Science and Technology, Vol. 3, No. 4, 2010 
[2] H. H. Chang, Y. Wang, W. Yang, "The impact of e-service quality, customer satisfaction and loyalty on e-marketing: Moderating effect of perceived value", Total Quality Management \& Business Excellence, Vol. 20, No. 4, pp. 423-443, 2009

[3] N. Sukasame, "The development of e-service in Thai government", BU Academic Review, Vol. 3, No. 1, pp.17-24, 2004

[4] S. Kim, L. Stoel, "Apparel retailers: Web site quality dimensions and satisfaction", Journal of Retailing and Consumer Services, Vol. 11, No. 2,pp. 109-117, 2004

[5] R. Zhou, X. Wang, L. Zhang, H. Guo, "Who tends to answer openended questions in an e-service survey? the contribution of closedended answers", Behaviour \& Information Technology, Vol. 36, No. 12, pp. 1274-1284, 2017

[6] Z. Yang, S. Cai, Z. Zhou, N. Zhou, "Development and validation of an instrument to measure user perceived service quality of information presenting web portals", Information \& Management, Vol. 42, No. 4, pp. 575-589, 2005

[7] M. Kim, J. H. Kim, S. Lennon, "Online service attributes available on apparel retail web sites: an E-S-QUAL approach", Managing Service Quality, Vol. 16, No. 1, pp. 51-77, 2006

[8] C. Sohn, S. K. Tadisina, "Development of e-service quality measure for internet-based financial institutions", Journal of Total Quality Management \& Business Excellence, Vol. 19, No. 9, pp. 903-918, 2008

[9] M. Wolfinbarger, M. C. Gilly, "E-TailQ: Dimensionalizing, measuring and predicting etail quality", Journal of Retailing, Vol. 79, No. 3, pp. 183-198, 2003

[10] B. Yoo, N. Donthu, "Developing a scale to measure the perceived quality of an internet shopping site (Sitequal)", Quarterly Journal of Electronic Commerce, Vol. 2, No. 1, pp. 31-47, 2001

[11] H. Li, R. Suomi, "A proposed scale for measuring e-service quality", International Journal of $\mathrm{u}$ - and e-Service, Science and Technology, Vol. 2, No. 1, 2009

[12] J. Santos, "E-service quality: a model of virtual service quality dimensions", Managing Service Quality, Vol. 13, No. 3, pp. 233-246, 2003

[13] C. H. Liao, H. R. Yen, E. Y. Li, "The effect of channel quality inconsistency on the association between e-service quality and customer relationships", Internet Research, Vol. 21, No. 4, pp. 458-478, 2011

[14] R. Vidgen, S. J. Barnes, “An integrative approach to the assessment of ecommerce quality", Journal of Electronic Commerce Research, Vol. 3, No. 3, pp. 114-127, 2006

[15] T. W. D. Kao, W. T. Lin, "The relationship between perceived eservice quality and brand equity: A simultaneous equations system approach", Computers in Human Behavior, Vol. 57, pp. 208-218, 2016

[16] H. Li, S. Reima, "A proposed scale for measuring e-service quality", International Journal of $\mathrm{u}$ - and e-Service, Science and Technology, Vol. 2, No. 1, 2009

[17] V. A. Zeithaml, "Service excellence in electronic channels", Managing Service Quality: An International Journal, Vol. 12, No. 3, pp. 135-139, 2002

[18] V. A. Zeithaml, A. Parasuraman, A. Malhotra, A conceptual framework for understanding e-service quality: Implications for future research and managerial practice, Marketing Science Institute, 2000

[19] A. P. Parasuraman, V. A. Zeithaml, A Malhotra, "E-s-qual: A multipleitem scale for assessing electronic service quality", Journal of Service Research, Vol. 7, No. 3, pp. 213-233, 2005

[20] Z. Yang, M. Jun, "Consumer perception of e-service quality: From internet purchaser and non-purchaser perspectives", Journal of Business Strategies, Vol. 19, No. 1, pp. 19-41, 2002

[21] M. Amin, "Internet banking service quality and its implication on ecustomer satisfaction and e-customer loyalty", International Journal of Bank Marketing, Vol. 34, No. 3, pp. 280-306, 2016

[22] H. H. Bauer, T. Falk, M. Hammerschmidt, "eTransQual: A transaction process-based approach for capturing service quality in online shopping”, Journal of Business Research, Vol. 59, No. 7, pp. 866-875, 2006
[23] P. Shachaf, M. S. Oltmann, S. Horowitz, "Service equality in virtual reference", Journal of the American Society for Information Science and Technology, Vol. 59, No. 4, pp. 535-550, 2008

[24] E. K. Yarimoglu, "A review of service and e-service quality measurements: Previous literature and extension", Journal of Economic and Social Studies, Vol. 5, No. 1, pp. 169-200, 2015

[25] C. N. Madu, A. A. Madu, "Dimensions of equality", International Journal of Quality \& Reliability Management, Vol. 19, pp. 246-258, 2002

[26] J. Carlson, A. O'Cass, "Exploring the relationships between e-service quality, satisfaction, attitudes and behaviours in content-driven eservice web sites", Journal of Services Marketing, Vol. 24, No. 2, pp. $112-127,2010$

[27] J. Minjoon, C. Shaohan, "The key determinants of Internet banking service quality: A content analysis", International Journal of Bank Marketing, Vol. 19, No. 7, pp. 276-291, 2001

[28] S. Kundu, S. K. Datta, "Impact of trust on the relationship of e-service quality and customer satisfaction", Euromed Journal of Business, Vol. 10 , No. 1, pp. 21-46, 2015

[29] J. Cox, B. G. Dale, "Service quality and e-commerce: An exploratory analysis", Managing Service Quality: An International Journal, Vol. 11, No. 2, pp. 121-131, 2001

[30] F. Davis, "Perceived usefulness, perceived ease of use, and user acceptance of information technology", MIS Quarterly, Vol. 13, No. 3, pp. 319-340, 1989

[31] Y. Lee, K. A. Kozar, K. R. T. Larsen, "The technology acceptance model: Past, present, and future", Communication of the Association for Information Systems, Vol. 12, No. 50, pp. 752-780, 2003

[32] E. T. Loiacono, R. T. Watson, D. L. Goodhue, "WebQual"M: A measure of Web site quality", AMA Winter Conference Austin, USA, 2002

[33] Z. Yang, X. Fang, "Online service quality dimensions and their relationships with satisfaction: A content analysis of customer reviews of securities brokerage services", International Journal of Service Industry Management, Vol. 15, No. 3, pp.302-326, 2004

[34] V. Venkatesh, H. Bala, "Technology acceptance model 3 and a research agenda on interventions", Decision Science, Vol. 39, No. 2, pp. 273-315, 2008

[35] D. Gefen, E. Karahanna, D. W. Straub, "Trust and TAM in online shopping: an integrated model", MIS Quarterly, Vol. 27, No. 1, pp. 5190,2003

[36] R. Sylvie, F. Ina, "A new measure of e-service quality in France", International Journal of Retail \& Distribution Management, Vol. 38, No. 7, pp. 497-517, 2010

[37] F. Liebana-Cabanillas, F. Munoz-Leiva, J. Sanchez-Fernandez, M. I. Viedma-del Jesus, "The moderating effect of user experience on satisfaction with electronic banking: Empirical evidence from the Spanish case", Information Systems and e-Business Management, Vol. 14, No. 1, pp. 141-165, 2016

[38] Z. Al-Adawi, S. Yousafzai, J. Pallister, "Conceptual Model of Citizen Adoption of E-Government", Second International Conference on Innovations in Information Technology, Dubai, UAE, 2005

[39] R. Zhou, X. Wang, Y. Shi, R. Zhang, L. Zhang, H. Guo, Measuring EService Quality and its Importance to Customer Satisfaction and Loyalty: An Empirical Study in a Telecom Setting, Springer, 2018

[40] J. Ojasalo, "E-service quality: A conceptual model", International Journal of Arts and Sciences, Vol. 3, No. 7, pp. 127-143, 2010

[41] E. E. Izogo, "Customer loyalty in telecom service sector: The role of service quality and customer commitment", The TQM Journal, Vol. 29, No. 1, pp. 19-36, 2017

[42] M. C. Minimol, "E-service quality and perceived value as predictors of customer loyalty towards online supermarkets", Asian Social Science, Vol. 14, No. 3, pp. 71-77, 2018

[43] S. Elo, H. Kyngas, "The qualitative content analysis process", Journal of Advanced Nursing, Vol. 62, No. 1, pp. 107-115, 2008

[44] F. B. Zavareh, M. S. M. Ariff, A. Jusoh, N. Zakuan, A. Z. Bahari, M. Ashourian, "E-service quality dimensions and their effects on e- 
customer satisfaction in internet banking services", Procedia-Social and Behavioral Sciences, Vol. 40, pp. 441-445, 2012

[45] Y. Zhang, B. Wildemuth, "Qualitative analysis of content", in: Applications of Social Research Methods to Questions in Information and Library Science, ABC-CLIO, 2009

[46] H. F. Hsieh, S. E. Shannon, "Three approaches to qualitative content analysis", Qualitative Health Research, Vol. 15, No. 19, pp. 1277-1288, 2005

[47] N. Mathers, N. Fox, A. Hunn, Trent Focus for Research and Development in Primary Health Care: An Introduction to Qualitative Research, Trent Focus, 2001

[48] S. Sahadev, K. Purani, "Modelling the consequences of e-service quality", Marketing Intelligence \& Planning, Vol. 26, No. 6, pp. 605620, 2008

[49] B. C. Cetinsoz, "The influence of e-service quality on customer perceived value: A study on domestics tourists in Turkey", International Journal of Science and Research, Vol. 4, No. 1, pp. 1265-1677, 2015

[50] H. Nourikhah, M. K. Akbari, "Impact of service quality on user satisfaction", Electronic Commerce Research and Applications, Vol. 17, pp. 112-122, 2016

[51] H. Surjadaja, S. Ghosh, J. Antony, "Determining and assessing the determinants of e-service operations", Managing Service Quality: An International Journal, Vol. 13, No. 1, pp. 39-53, 2003

[52] Z. Yang, M. Jun, R. T. Peterson, "Measuring customer perceived online service quality: Scale development and managerial implications", International Journal of Operation \& Productive Management, Vol. 24, No. 11, pp. 1149-1174, 2004

[53] Z. Yang, "Consumer perceptions of service quality in Internet based electronic commerce", Proceedings of the EMAC Conference, Vol. 811, EMAC, 2001

[54] E. Cristobal, C. Flavian, M. Guinaliu, "Perceived e-service quality (PeSQ): measurement validation and effects on consumer satisfaction and web site loyalty", Managing Service Quality: An International Journal, Vol. 17, No. 3, pp. 317-340, 2007

[55] M. Zhang, L. Huang, Z. He, A. G. Wang, "E-service quality perceptions: An empirical analysis of the Chinese e-retailing industry", Total Quality Management \& Business Excellence, Vol. 26, No. 11-12, pp. 1357-1372, 2015

[56] M. Askari, "Measuring e-service quality from the customers' perspective: An Empirical study on banking services", Journal of Marketing and Consumer Research, Vol. 24, pp. 57-68, 2016 